DOI: https://doi.org/10.34069/AI/2021.48.12.26

How to Cite:

Shmeleva, M.V. (2021). Unified procurement information system to control intergovernmental cooperation. Amazonia Investiga, 10(48), 248-253. https://doi.org/10.34069/AI/2021.48.12.26

\title{
Unified procurement information system to control intergovernmental cooperation
}

\section{Единая информационная система закупок для контроля межправительственного сотрудничества}

Received: November 11, 2021

\begin{abstract}
This paper concentrates on the prospects for the intergovernmental cooperation which can create a stable basis for improving existing information tools and setting up the innovative means of legal regulation in the field of digital public procurement. The purpose of the study is to propose a modern model for the state regulation of procurement activities. The study supports the idea of the universal digital transformation of public procurement systems all over the world. It is also supposed to demonstrate what problems a newly developed model, aimed at introducing well-based digital public procurement, might face at the legislative level. The dataset has been obtained using dialectical, logical, comparative, and legal research methods. The tools used to assess the possibility of developing an legal regulation model in the field of public procurement can be applied by public authorities in various countries and international communities.
\end{abstract}

Keywords: intergovernmental cooperation, legal regulation, public procurement, digitalization, Unified Procurement Information System (UPIS).
Accepted: December 19, 2021

Written by:

Marina V. Shmeleva110

https://orcid.org/0000-0002-1628-8366

Researcher ID: P-6997-2017

\begin{abstract}
Аннотация
В данной статье основное внимание уделяется перспективам межправительственного сотрудничества, которое может создать устойчивую основу для совершенствования существующих информационных инструментов и создания инновационных средств правового регулирования в области цифровых государственных закупок. Цель исследования - предложить современную модель государственного регулирования закупочной деятельности. Исследование поддерживает идею всеобщей цифровой трансформации систем государственных закупок во всем мире. Предполагается также продемонстрировать, с какими проблемами может столкнуться недавно разработанная модель, направленная на внедрение хорошо обоснованных цифровых государственных закупок на законодательном уровне. Набор данных был получен с использованием диалектических, логических, сравнительных и юридических методов исследования. Инструменты, используемые для оценки возможности разработки модели правового регулирования в сфере государственных закупок, могут быть применены государственными органами в различных странах и международных сообществах.
\end{abstract}

Ключевые слова: Государственные закупки, цифровизация, межгосударственное взаимодействие, модель, правовое регулирование, цифровые технологии, Единая Информационная Система Закупки (ЕИСЗ).

\footnotetext{
${ }^{110}$ Assistant professor Civil Law Department Saratov State Law Academy, Saratov, Russia.
} 


\section{Introduction}

Innovative technologies and digital ecosystems are currently dictating their terms to the world. This is also true for public procurement, which has gained significant importance and a leading position in the digital economy structure. The legal area of the world economy players' interaction is primarily intended to meet public needs for goods, works, and services that are available at present and will be available in the future through government programs or national projects of individual countries and their communities. These programs and projects are designed to represent the interests of a particular community. In the field of public procurement, it is also essential to realize the maximum possible budgetary and extra-budgetary savings. We mean the funds allocated for the implementation of proposed programs, projects, etc., which promote the production of innovative things, introduction of high-tech technologies along with support for small and medium-sized businesses as well as socially oriented non-profit organizations (Shmeleva, 2020).

Most economically developed countries are very much focused on the development, introduction, and implementation of digital procurement processes or deliberately moving towards electronic procurement schemes. The global experience of digital public procurement is based on a central web-platform for monitoring procurement processes with high management efficiency at each stage. There are six main stages of a procurement process:

1. Planning.

2. Preparation (it is the most time-consuming stage since it involves determining the method of procurement, collecting the information necessary for the placement of the purchase order, preparing the package of accompanying documents, and drafting the government procurement agreement with all its terms and conditions).

3. Procurement itself.

4. Assessment of the procurement results and the conclusion of the government procurement agreement between the parties involved.

5. Performance of the government procurement agreement in compliance with all its terms and conditions.

6. Reports on the performance of the government procurement agreement in terms of a specific purchase along with subsequent monitoring and auditing.
The operational stages of any procurement process require legal support that would promote the interests of all the participants. It should be noted that spending budgetary funds, which is the main source of financing public procurement, is subject to special supervision. There is a separate procedure for assessing its efficiency. However, effective and stable contractual relations are a very complicated thing because on an international scale, the legal regulation of the digital economy is not very well developed (Akimov and Konajkov, 2018).

Digital opportunities in the context public procurement systems of different countries may vary, but the variations are not fundamental. All the systems of this sort are similar to the Russian Unified Procurement Information System. Under Article 3 of the Federal Law No. 44-FZ of Apri, 2013 on the Contractual System in the Area of Procurement of Goods, Works, and Services for Meeting State and Municipal Needs, procurement is a set of information data, information technologies, and technical support that can provide, process, and store the formation about procurement activities along with the further presentation of this information in electronic form (The Federal Law No. 44-FZ, 2013).

Contemporary procurement electronic systems make it possible for all the involved parties to get unimpeded access to information resources. It means that the electronic systems play a crucial role in public procurement. Today, among all the other things, such systems are used for standardization and automation of all stages of a procurement process. By that, the influence of human factors may be substantially reduced. The same is true for the total time spent on solving tasks. In addition, public procurement digitalization allows new participants to easily enter the market. That is certainly good from the point of healthy competition and cutting operating costs.

Despite the novelty of the research issues related to global economy digitalization in general and to public procurement legal regulation in particular, experts from various scientific fields have paid attention to the problems in question. There are many works that are worth mentioning. These are the works of T. A. Guseva (Guseva, Demenina, \& Smetanina, 2020), V. V. Kikavets \& Y. K. Tsaregradskaya (Kikavets and Tsaregradskaya, 2020), J. Nemec (Nemec, Kubak, Donin, \& Kotherova, 2021), 
Y. A. Gavrilova (Gavrilova, Kvitsinia, \& Kalashnikova, 2020), M. Rašić (Rašić, Milenkovic, \& Vojkovic, 2019), E. M. Styrin \& Y. D. Rodionova (Styrin and Rodionova, 2020), T. Tátrai \& G. Vörösmarty (Tátrai and Vörösmarty, 2020), etc. But currently, the studies of the issues related to the legal support of digital public procurement at the international level cannot generate a holistic foundation for the development of a comprehensive model with effective measures to modernize the present-day public procurement legislation. There is still no scientific literature and works, which can serve as a stable basis for the development of digital infrastructure in this area.

\section{Methods}

The study is based on the analysis of international legislation of public procurement, including the use of digital technologies. Such documents as the Treaty on the Eurasian Economic Union (United Nations UNCTAD, 2014), Directive of the European Parliament and of the Council on public procurement and repealing Directive 2004/18/EC (Directive 2014/24/EU, 2014), European Commission Regulation №2019/1780 establishing standard forms for the publication of notices in the field of public procurement and repealing Implementing Regulation (EU) 2015/1986 (eForms) (2019), WTO Agreement on Government Procurement (World Trade Organization, 2012) and others. The dataset has been obtained using dialectical, logical, comparative, and legal research methods.

\section{Discussion}

In the international context, the digitalization of public procurement should be closely related to the creation of e-government. E-government is a key factor in uniting public administration within the framework of digital economy. It is necessary to open the door to management decision making on the quality of public spending. The decisions should be based on the data obtained during the public procurement process. The digital tools proposed in the model, for example, cataloging regulatory legal instruments and the identification of purchases, should contribute to the adjustment of public spending to actual data, providing for its transparency, consistency, and maximum integration with current market conditions (Egorova et al., 2021).

The systematic list of procured goods, works, and services should be in the form of a catalog generated electronically on the basis of the International Standard Industrial Classification of All Economic Activities adopted by the UN (United Nations, 2008). This list should be placed in the international procurement information system and contain common names of procurement objects. Among other things, a unique digital code should be assigned to the each element of the catalog. The procedure for the formation and maintenance of the catalog as well as the rules for its use should be established by international e-government.

On top of it, a prerequisite for the implementation of a legal support model for digital public procurement is undoubtedly its legal categorization. At the international level, a list of standard agreement samples and their terms and conditions should be developed and adopted. These samples are supposed not only to relieve public customers of the burden related to drafting agreements, but also to increase the transparency of procurement activities in general. All these factors make the development of an innovative public procurement legal regulation model essential for this area.

The universal digitalization of public procurement requires high-profile data analyses since that is one of the main indicators integral to the legal regulation of international cooperation in this area. At the legislative level, the international community seeks to encourage private sector representatives to participate in tenders and cooperate in joint associations as procurement participants. This will contribute to the growth of small and medium-sized businesses as well as increasing competition on the global market. Mutually beneficial cooperation goals will be achieved, while creating additional jobs in various sectors of the economy (Shmeleva, 2020).

However, there are obstacles on the way to international cooperation, namely procurement participants' reluctance and fear that regulatory authorities will interfere too much with their activities; the lack of legal standards covering procurement processes; significant financial investments in technical support and support of procurement participants, etc. Among other things, there are still personal ties between customers and suppliers of goods works, and services, which have been developed over the past years of cooperation. This fact can influence procurement participants' decision-making very much.

When conducting procurement procedures in electronic form, the information technologies used cannot fully ensure unhindered access to 


\section{AMAZOND瓜}

information and proper protection of participants in the contractual system in the field of procurement from unfair actions of entities using, among other things, various computer systems.

The use of information technology contributes to the development of a number of related problems:

- the use of software robots in electronic trading to collect information for the purpose of collusion;

- the use of special accounts created for automatic sending of messages via regular or group chats (for example, Telegram);

- conducting "negotiations" by the participants of public procurement with the intention to conclude an anti-competitive agreement;

- technical capabilities that ensure the victory of a competitor by blocking other participants in the purchase, etc.

To prevent the influence of negative factors at the level of intergovernmental cooperation, participants in digital public procurement are invited to use an innovative tool, which is called a distributed registry technology. The technology is supported by a distributed computing network that provides data recording, storage, and protection against unauthorized access and alterations (Kikavets, Tsaregradskaya, 2020).

The key question in developing a model for the legal regulation of well-based public procurement at the international level is not only about its innovative nature, but also about its role as a unified information space for all the sectors of the world economy. The basic requirement for the model is its ability to track identification codes and control the funds allocated for purchases. This information should be reflected in the documents to be sent electronically through a unified payment and information system. In addition, the model should provide for the use of a qualified electronic signature to sign digital documents. Thus, the model of legal support for digital public procurement is not limited to a single goal. It has to do with a multifunctional methodological approach (Egorova et al., 2021).

In addition to electronic data that should be collected, stored, and processed, the model requires coded software with codes of various levels of complexity. This is necessary to maintain business processes at all stages of the procurement as well as to allow for the efficient use of all available and prospective analytical mechanisms and procurement control tools. The development of the model of this kind, in addition to ensuring international cooperation of public procurement participants, is aimed at universal digitalization of economic and legal spheres. It will surely enlarge economic and geographical boundaries as well as the opportunities of States through expanding supply and sales markets, saving financial and time resources, increasing the level of legal protection while providing access to public procurement for market participants. It will also ensure the transparency of the procurement process and the possibility for collecting statistical data in order to analyze their structural and dynamic characteristics.

The intended effect of the developed legal regulation model to control intergovernmental cooperation in digital public procurement is, first of all, in the streamlining public relations arising from the digital economy development. The result will be the strengthening of the legislative foundation and legal support for the use of innovative technologies as well as ensuring legal coordination of various entities operating in digital public procurement. It is expected that during the implementation of the proposed model, a number of regulations will be developed and adopted, which will lead to economic, social, and legal changes in the field of digital public procurement.

Among the economic consequences of the implementation of the model, a change in the world economic development is expected. This change will allow the world economy to overcome the current crisis and get to a fundamentally new level. Digital technologies will boost the technological development of the countries, participating in the unified digital public procurement system. This will surely contribute to increasing global GDP.

The social consequences of the proposed model will be expressed in overcoming poverty on a global scale. This goal is expected to be achieved by improving the public administration system based on digital technologies. Consequently, there will be a need for qualified staff, working in the field of digital procurement. These people will require special training and educational systems of the world will have to adjust to the demand. Thus, digital technologies will boost the service sector. Services will become more accessible to people in various parts of the world. The unemployment rate will go down on a global scale. This will be achieved by creating remote jobs and using digital technologies for this 
purpose. The new digital economy will minimize imbalances in the social and economic development of individual countries. This will contribute to improving people's welfare.

\section{Conclusions}

Summing up the results of this research, we can say that despite the exceptional attention to the issues of public procurement digitalization at the international level, its potential has not been fully recovered yet. The legal support in this area is rather inadequate. International cooperation in the field of public procurement should be focused on the centralization, unification, cataloging, and simplification of procurement rules.

The model proposed for improving legal support in the sphere of digital public procurement is aimed at eliminating legal gaps, contradictions, and controversial situations that often arise in the international regulation of digital economic relations. The proposed comprehensive legal regulation will create a foundation for the development of the digital economy on the international market. This will also eliminate many complications associated with the use of digital technologies in various economic sectors, including international economic cooperation.

Summing up the study from the point of view of its applicability to international experience, it should be noted that the idea of developing an innovative model of legal regulation on the development of digital public procurement deserves attention and suggests that this experience may well be implemented both by developing and developed states.

\section{Acknowledgments}

The reported study was funded by the RFBR as part of the scientific project No. 20-011-00140 A "Introduction of modern civil law mechanisms in the field of public procurement as a system of measures to ensure effective and efficient use of budget funds, as well as creating conditions for ensuring positive structural changes in the economy and social sphere", 2020-2022.

\section{Bibliographic references}

Akimov, N. A., \& Konajkov, M. A. (2018). International Legal Regulation of Public Procurement. Moscow: MGUU Moscow government, 80 p. (In Russian)

Directive 2014/24/EU of the European Parliament and of the Council of 26 February 2014 on public procurement and repealing
Directive 2004/18/EC (2014). Available at: https://roszakupki.ru/upload/iblock/9bf/CEL EX-32014L0024-EN-TXT.pdf.

Egorova, M., Andreeva, L., Andreev, V., Tsindeliani, I., \& Kikavets, V. (2021). Digitalization of Public Procurement in the Russian Federation: Case Study. The NISPAcee Journal of Public Administration and Policy, Vol. XIV, No. 1, Summer, pp. 87-106.

Gavrilova, J.A, Kvitsinia, N.V., $\&$ Kalashnikova, N.A. (2020). Development of the Institute of Public Procurement in Modern Russia: Between Blockchain and Administration. Competitive Russia: Foresight Model of Economic and Legal Development in the Digital Age. Lecture Notes in Networks and Systems. New York, NY: Springer,

pp. 388394.

Guseva, T.A., Demenina, E.A., \& Smetanina, E.E. (2020). Improving the System of State (Municipal) Procurement as a Factor for Stimulating Competition in the Digital Economy. Industry Competitiveness: Digitalization, Management, and Integration. ISCI 2019. Lecture Notes in Networks and Systems, 115. Cham: Springer, pp. 253-258.

Kikavets, V.V., \& Tsaregradskaya, Y.K. (2020). The Implementation of Principles of the Budget Process in the Financing of Public Procurement in the Digital Economy. Artificial Intelligence: Anthropogenic Nature vs. Social Origin. New York, NY: Springer, pp. 28-35.

Nemec, J., Kubak, M., Donin, G., \& Kotherova, Z. (2021). Efficiency of Public Procurement in the Czech and Slovak Health Care Sectors. Transylvanian Review of Administrative Sciences, 62, pp. 115-133.

Rašić, M., Milenkovic, M., \& Vojkovic, G. (2019). Electronic Auction in European and Croatian Public Procurement Law. In M. Koricic (ed.). 42nd International Convention on Information and Communication Technology, Electronics and Microelectronics (MIPRO). Opatija, Croatia: IEEE, pp. 1343-1348.

Shmeleva, M.V. (2020). Electronic Public Procurement as a Way to Effectively Spend the Budget: International Experience. Saratov State Law Academy Bulletin, No 3 (134), pp. 151-154. (In Russian)

Styrin, E.M., \& Rodionova, J.D. (2020). Unified Information System in the Field of Procurement as a Governmental Digital Platform: Current State and Prospects. Governmental Issues, No 3, pp. 49-70. (In Russian) 
Tátrai, T., \& Vörösmarty, G. (2020). NonCompliance in Public Procurement Comparative Study under EU Law. Transylvanian Review of Administrative Sciences, 61, pp. 143-161.

The Federal Law No. 44-FZ. On the Contractual System in the Area of Procurement of Goods, Works, and Services for Meeting State and Municipal Needs of April 5 (2013). Available at:

http://www.consultant.ru/document/cons_do c_LAW_144624/.

United Nations (2008). International Standard Industrial Classification of All Economic Activities, Revision 4. New York Available at:

https://unstats.un.org/unsd/publication/series $\mathrm{m} /$ seriesm_4rev4e.pdf

United Nations UNCTAD (2014). The Treaty on the Eurasian Economic Union. Available at: https://investmentpolicy.unctad.org/internati onal-investment-agreements/treaties/treatieswith-investment-provisions/3471/treaty-oneurasian-economic-union-2014.

World Trade Organization (2012). Agreement on Government Procurement and related WTO legal texts Available at: https://www.wto.org/english/docs_e/legal_e/ rev-gpr-94_01_e.pdf. 